\title{
Numerical Simulation of Ethanol Production for Different Carbon Sources Using Thermotolerant Kluyveromyces Marxianus
}

\author{
Hidayatullah Mahar ${ }^{1}$, Abdul Sattar Jatoi ${ }^{1}$, Imran Nazir Unar², Irshad Ali Gopang ${ }^{3}$, Makhdoom Naeem ${ }^{4}$, \\ Mohammad Siddique ${ }^{5}$ \\ 1Department of Chemical Engineering, NFC IET, Multan, Pakistan, ${ }^{2}$ Department of Chemical Engineering, MUET, \\ Jamshoro, Pakistan, ${ }^{3}$ Institute of Petroleum and Natural Gas Engineering Mehran University of Engineering \& \\ Technology, Jamshoro, Pakistan, ${ }^{4}$ Department of Computer System, NFC Institute of Engineering \& Technology, \\ Multan, Pakistan, ${ }^{5}$ Department of Chemical Engineering, Faculty of Engineering and Architecture, Balochistan \\ University of Information Technology, Engineering and Management Sciences, Quetta, Pakistan
}

\begin{abstract}
During process of fermentation a variety of parameters effect on ethanol production, current work focusses to investigate the effect of different carbon sources on ethanol production using numerical simulation. The fermentation process was carried out using microprocessor-controlled fermenter in which different types of carbon sources were studied like glucose, sucrose and molasses from $10 \%$ to $15 \%$ of range. The model proposed by Monod was found to be more appropriate for describing the batch growth and ethanol production using kluyveromyces marxianus. The maximum yield of ethanol production took place using $15 \%$ molasses as carbon source. The maximum ethanol production $(76 \mathrm{~g} / \mathrm{ll})$ was observed at $15 \%$ molasses, as for sucrose and glucose are concerned it gives lower value of ethanol production up to $73 \mathrm{~g} / \mathrm{l}$ by keeping other operational parameter under optimized condition such are $35^{\circ} \mathrm{C}, 300 \mathrm{rpm}, 0.2 \mathrm{vvm} / \mathrm{l}$ and $\mathrm{pH} 5.5$. Approximately same results were achieved by using experimental data and model execution.
\end{abstract}

Keywords: Carbon Source; Ethanol; Kluyveromyces Marxianus; Fermenter; Glucose; Molasses; Sucrose

Corresponding author's email: maharhidayatullah@gmail.com

\section{INTRODUCTION}

World researchers are focusing their cumulative attention on renewable and clean fuel cell like Bio-ethanol, because of its environmental benefits. Bio-ethanol is produced by using different renewable feedstock like e.g. cassava ( $1^{\text {st }}$ generation), corn, cellulose biomass $\left(2^{\text {nd }}\right.$ generation) sugarcane, algae biomass ( $3^{\text {rd }}$ generation) and wheat (Baeyens, 2015). By product of sugar industry say molasses, is easily convertible into bio fuel by fermentation. It is mostly used because of easy availability and low cost. Variation up to $50-55 \%$ fermentable sugar for converting it into ethanol (Zayed, 1997). Ethanol production using microbial organisms is deliberated as renewable fuel for reduction of environmental impacts (Shenoy, 2011; Singhania, 2008). The raw materials which are rich in sugar can easily be converted into ethanol by kinetics of alcoholic fermentation using most useful microorganism saccharomyces cerevisiae (Najaf, 2004). The most convenient carbon source for metabolism is molasses which is an agro-industrial by-product frequently used in alcohol distilleries owing to the presence of fermentative sugars (Cazetta, 2007). Owing to gorgeous presence of sucrose it has been remained on the top of research interest to convert this sugar cane refining process, which presents a substrate not requiring pre-treatment prior to the fermentation. Productivity and substrate concentration remained major portion of inhibition of growth during traditional batch fermentation for distilled ethanol production using S. cerevisiae. Its limitation are 2.3 and $1.8 \mathrm{~g} / \mathrm{l} . \mathrm{hr}$ (Baptista, 2006). Molasses are a potential feedstock for ethanol production (Bouallagui, 2013). Ethanol has received worldwide attention as an alternative energy source mainly for transportation fuels production (Cardona, 2007; Walter, 2008). Mathematical modeling plays an important role to understand the fundamental relationship between different variables and give an economic way to optimize various parameters (Jatoi, 2016). Numerical simulation of ethanol production also discusses in our work with the utilization of Monod Model (Maher, 2017; Jatoi, 2016). But current work describes the utilization of numerical technique for optimization of carbon source for maximum ethanol production. 


\section{MATERIALS AND METHODS}

Programming $\mathrm{C}++$ was used to carry out numerical simulation by using Range Kutta (RK) order 4 as a numerical method to solve Monod model on the basis of experimental data.

Data was collected from previous work; Monod model was used to study the effects of different carbon sources on ethanol production. Initial conditions that were taken for numerical simulation are described here as $\mathrm{t}=0, \mathrm{Xo}=0 \mathrm{~g} / \mathrm{l}, \mathrm{so}=150 \mathrm{~g} / \mathrm{l}$ and $\mathrm{P}=0 \mathrm{~g} / \mathrm{l}$. $\mathrm{C}++$ program was developed for solving Monod model using RK $4^{\text {th }}$ order method.

Collection of

experimental

data
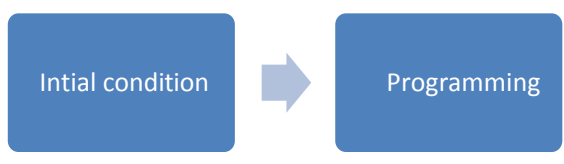
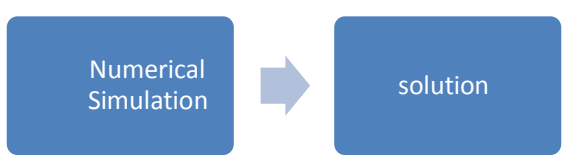

Figure 1: Block diagram showing steps from inception to end process

\section{RESULTS AND DISCUSSION}

\section{Effect of temperature on ethanol production using different carbon source}

Monod model was used to study the effects of temperature on ethanol production using different carbon sources such are sucrose, glucose and molasses. In this work the study was done at the temperatures of $40^{\circ} \mathrm{C}$ and $45^{\circ} \mathrm{C}$.A high temperature led to a decrease in the ethanol and cell yields but an increase in the inhibition effect of ethanol and sugar on cell growth and ethanol production (Phisalaphong, 2006). The maximum ethanol production was achieved at $40^{\circ} \mathrm{C}$. During process of fermentation microbial growth affected by different carbon sources, because microbes that were used have need of nutrients like carbon, sucrose, glucose and molasses. Numerical simulation was practiced by using Monod kinetic equation for cell growth, substrate utilization and ethanol production. In numerical simulation $\mathrm{C}++$ program was developed by utilizing RK order $4^{\text {th }}$ (Numerical method) to solve Monod model. The maximum ethanol production was observed at $40^{\circ} \mathrm{C}$ using $15 \%$ molasses. In figure 02 the maximum ethanol production was obtained at $40^{\circ} \mathrm{C}$ at $10 \%$ glucose. In figure 03 for sucrose the maximum ethanol production occurred at $15 \%$ at $40^{\circ} \mathrm{C}$ for comparison between these three carbon sources the maximum ethanol production was achieved by using molasses setting its concentration up to $15 \%$.

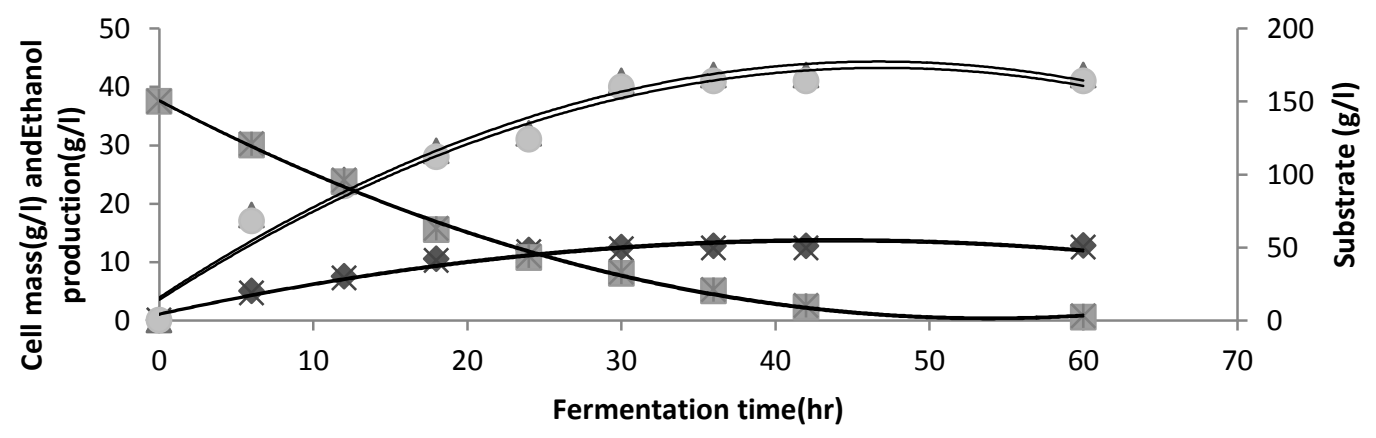
- Cell Mass $(\mathrm{g} / \mathrm{l})$ at $40 \mathrm{OC} \times$ Cell Mass $(\mathrm{g} / \mathrm{l})$ at $450 \mathrm{C} \triangle \mathrm{Ethanol}(\mathrm{g} / \mathrm{l})$ at $400 \mathrm{C}--$ Model results Ethanol $(\mathrm{g} / \mathrm{l}) 450 \mathrm{C} \quad$ Substrate $(\mathrm{g} / \mathrm{l})$ at $400 \mathrm{CO} \quad *$ Substrate $(\mathrm{g} / \mathrm{l}) 45 \mathrm{OC}$

Figure 2: Ethanol production using glucose as carbon source at $40^{\circ} \mathrm{C}$ and $45^{\circ} \mathrm{C}$ 


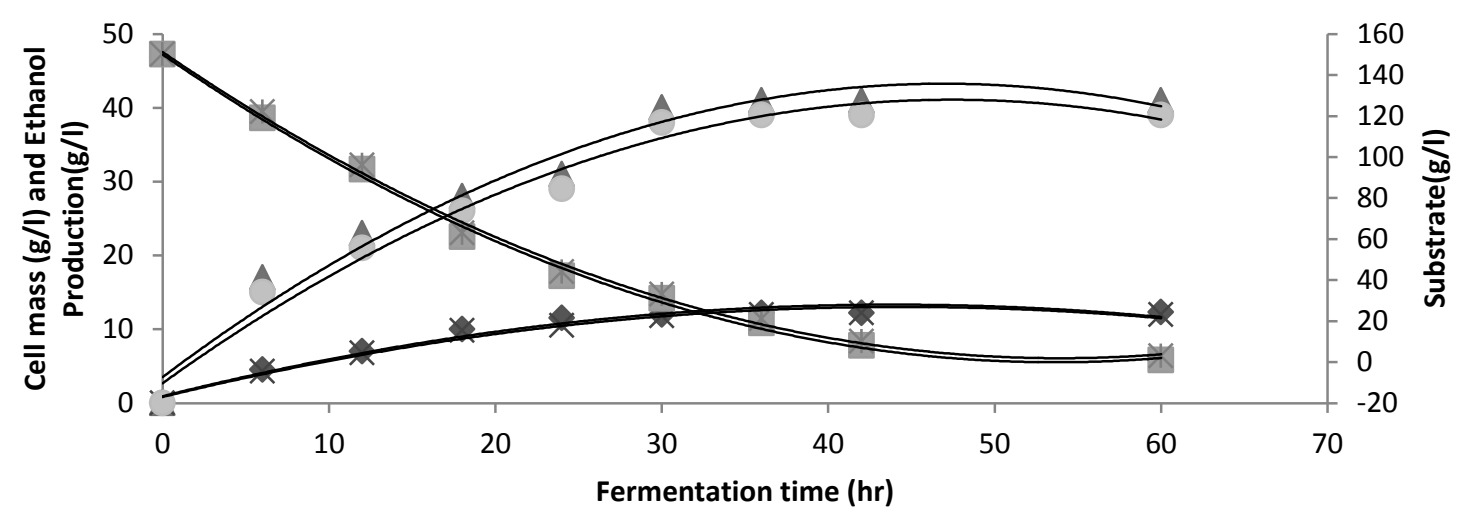

$\begin{array}{llll}\diamond \text { Cell Mass(g/l)40 OC } & \triangle \text { Production(g/l)40 OC } & \times \text { Cell Mass(g/l)45 OC } & \text {--Model results } \\ \text { Production(g/l)45 OC } & \text { Substrate(g/l)40 OC } & * \text { Substrate(g/l)45 OC }\end{array}$

Figure 3: Ethanol production using molasses as carbon source at $40^{\circ} \mathrm{C}$ and $45^{\circ} \mathrm{C}$

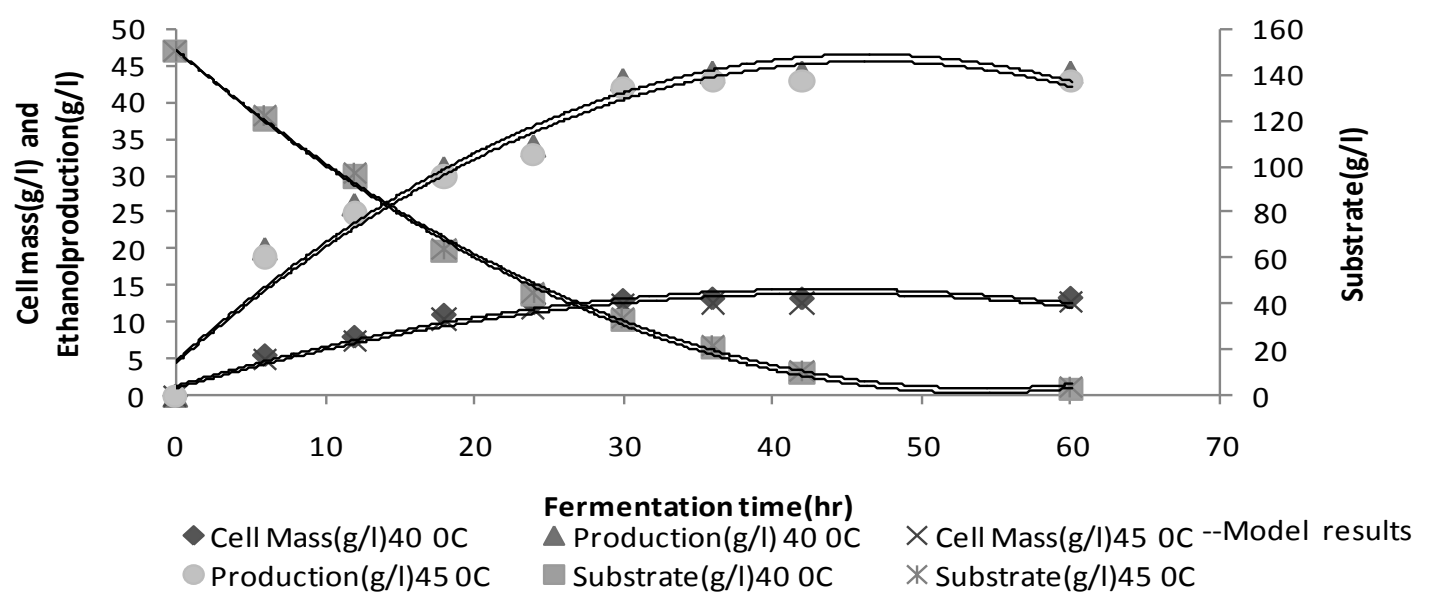

Figure 4: Ethanol production using sucrose as carbon source at $40^{\circ} \mathrm{C}$ and $45^{\circ} \mathrm{C}$

\section{Effect of oxygen flow rate on ethanol production using different carbon source}

During process of fermentation nutrients are used for cell growth of microorganism which will enhance the production of ethanol, by this process molasses is converted into ethanol at different operating parameters. Apart from this oxygen flowrate also plays main role in fermentation process, because of it optimization of oxygen flow rate was also done along with the carbon sources using numerical simulation RK $4^{\text {th }}$ order to solve Monod model. In figure 04 Sucrose is used as carbon source for using $0.1 \mathrm{vvm} / \mathrm{l}$ and $0.2 \mathrm{vvm} / \mathrm{but}$ the maximum production was observed at $0.1 \mathrm{vvm} / \mathrm{l}$ using $15 \%$ sucrose. The maximum ethanol production occurs at $10 \%$ glucose at $0.1 \mathrm{vvm}$. 


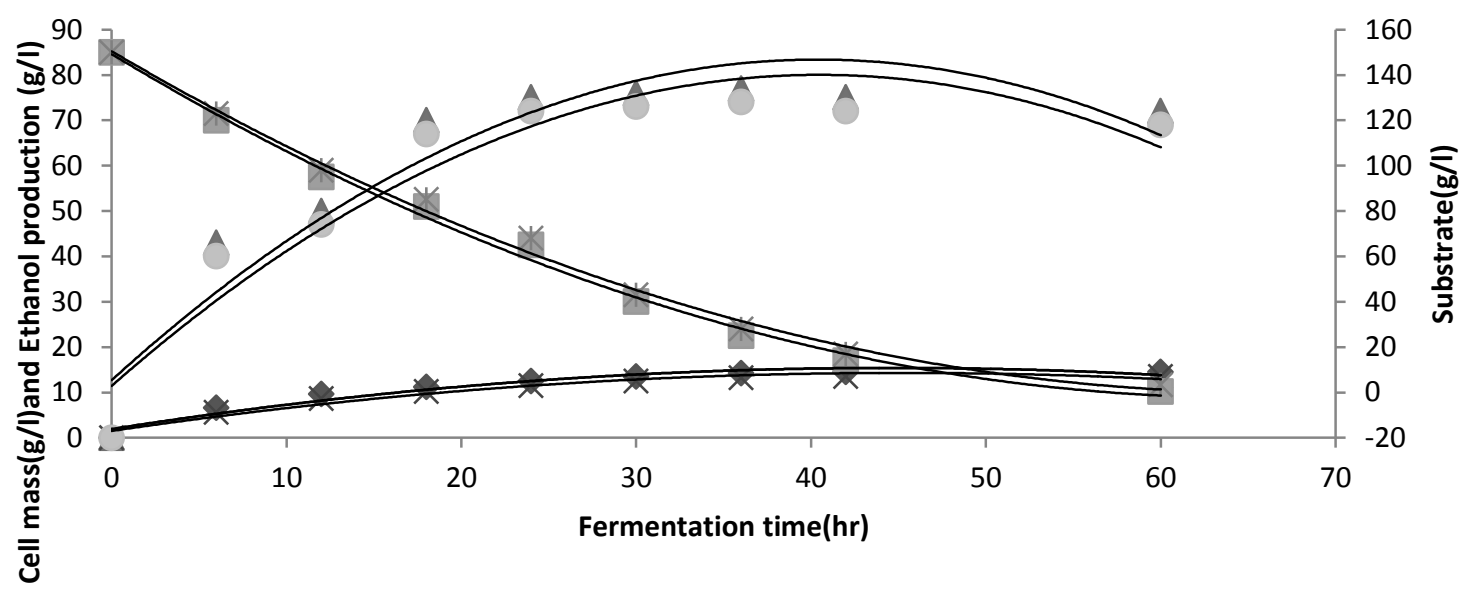

$\bullet$ Cell mass(g/l)0.1vvm/l $\Delta$ Ethanol(g/l)0.1vvm/l $\times$ Cell mass(g/l)0.2vvm/l $\quad$--Model results

Ethanol(g/l)0.2vvm/l a substrate(g/l)0.1vvm/l $*$ substrate(g/l)0.2vvm/l

Figure 5: Ethanol production using glucose as carbon source at $0.1 \mathrm{vvm} / \mathrm{l}$ and $0.2 \mathrm{vvm} / \mathrm{l}$

It is seen that the higher production of ethanol can be achieved by using molasses as compare to glucose.

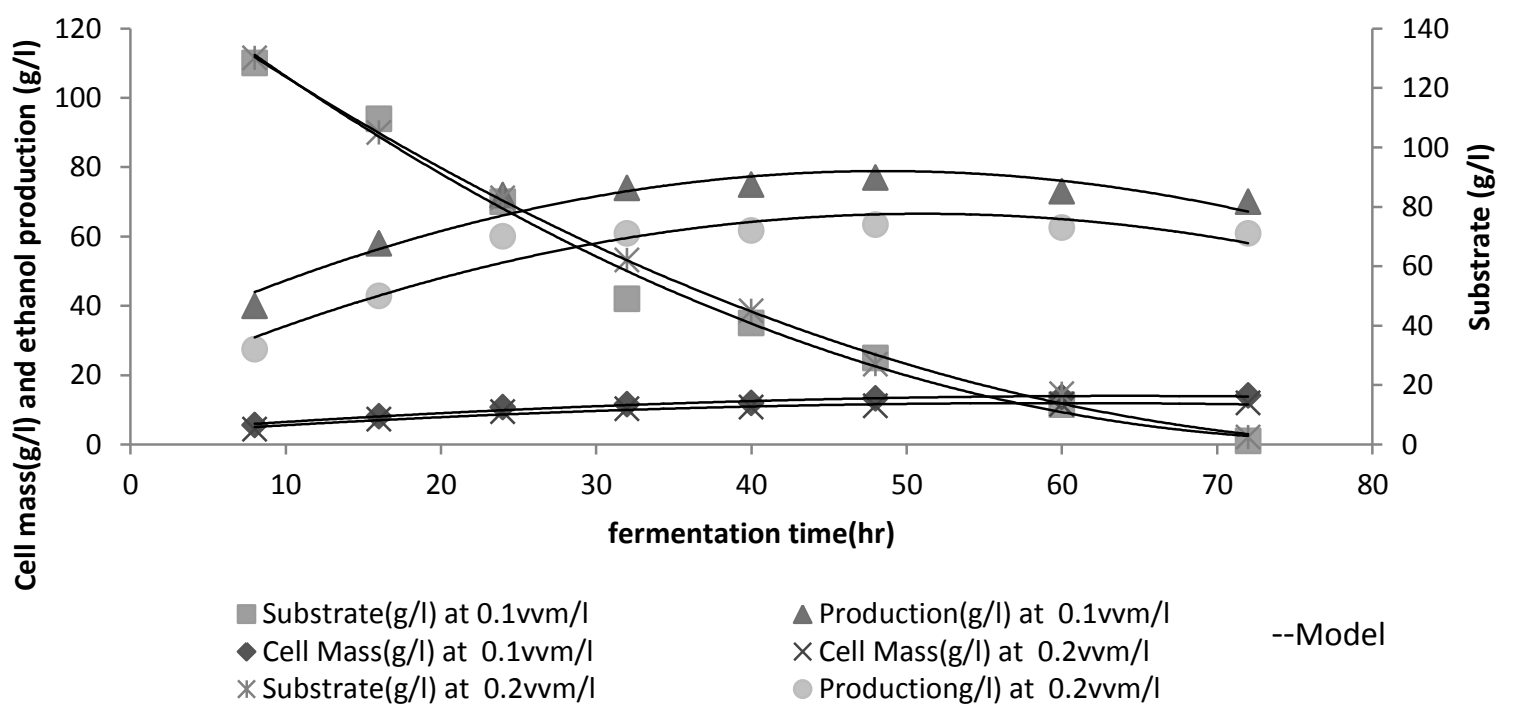

Figure 6: Ethanol production using molasses as carbon source at $0.1 \mathrm{vvm} / \mathrm{l}$ and $0.2 \mathrm{vvm} / \mathrm{l}$

\section{Effect of $\mathrm{pH}$ on ethanol production using different carbon source}

Rate of fermentation is very much influenced by $\mathrm{pH}$ while producing ethanol from bio materials Like, molasses, sugar, starch etc. Because of that $\mathrm{pH}$ is critically adjusted to achieve better production in different biological and chemical processes. 


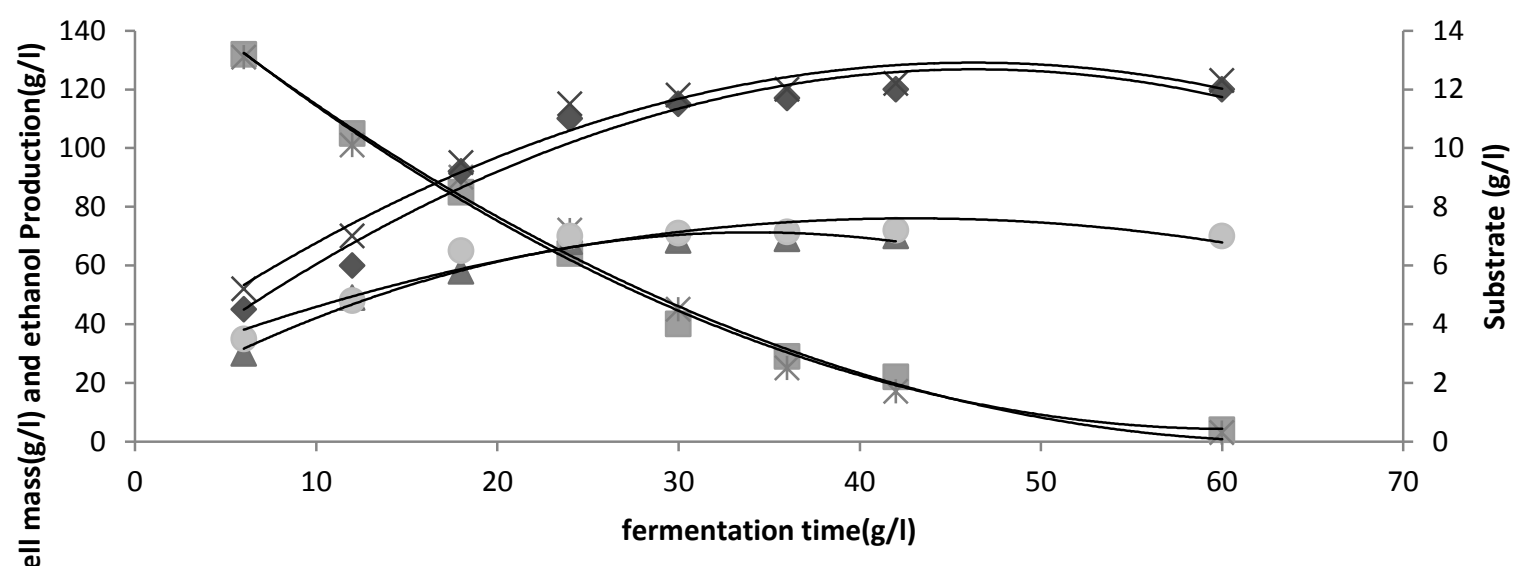

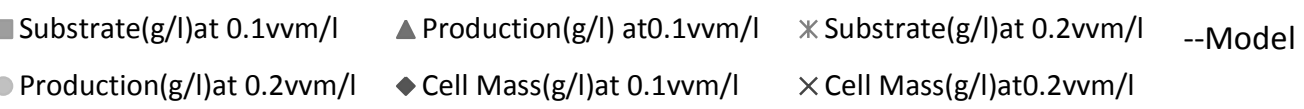

Figure 7: Ethanol production using sucrose as carbon source at $0.1 \mathrm{vvm} / \mathrm{l}$ and $0.2 \mathrm{vvm} / \mathrm{l}$

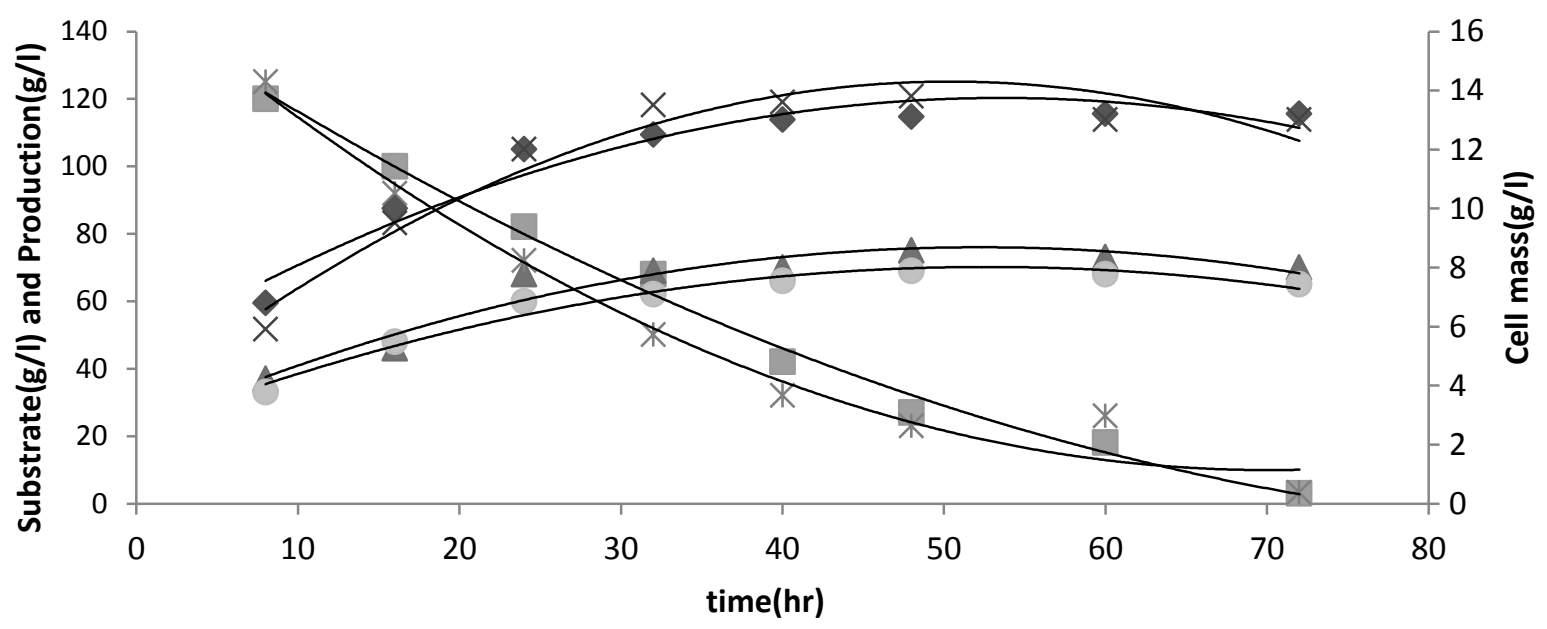

Substrate(g/l)at $5 \mathrm{Ph} \quad \Delta$ Production(g/l)at $5 \mathrm{pH} \quad *$ Substrate(g/l)at $5.5 \mathrm{pH} \quad--$ Model results

Production(g/l) at $5.5 \mathrm{pH} \diamond$ Cell Mass(g/l)at $5 \mathrm{pH} \quad \times$ Cell Mass(g/l)at $5.5 \mathrm{pH}$

Figure. 8: Ethanol production using glucose as carbon source at $\mathrm{pH}$ 5and 5.5 


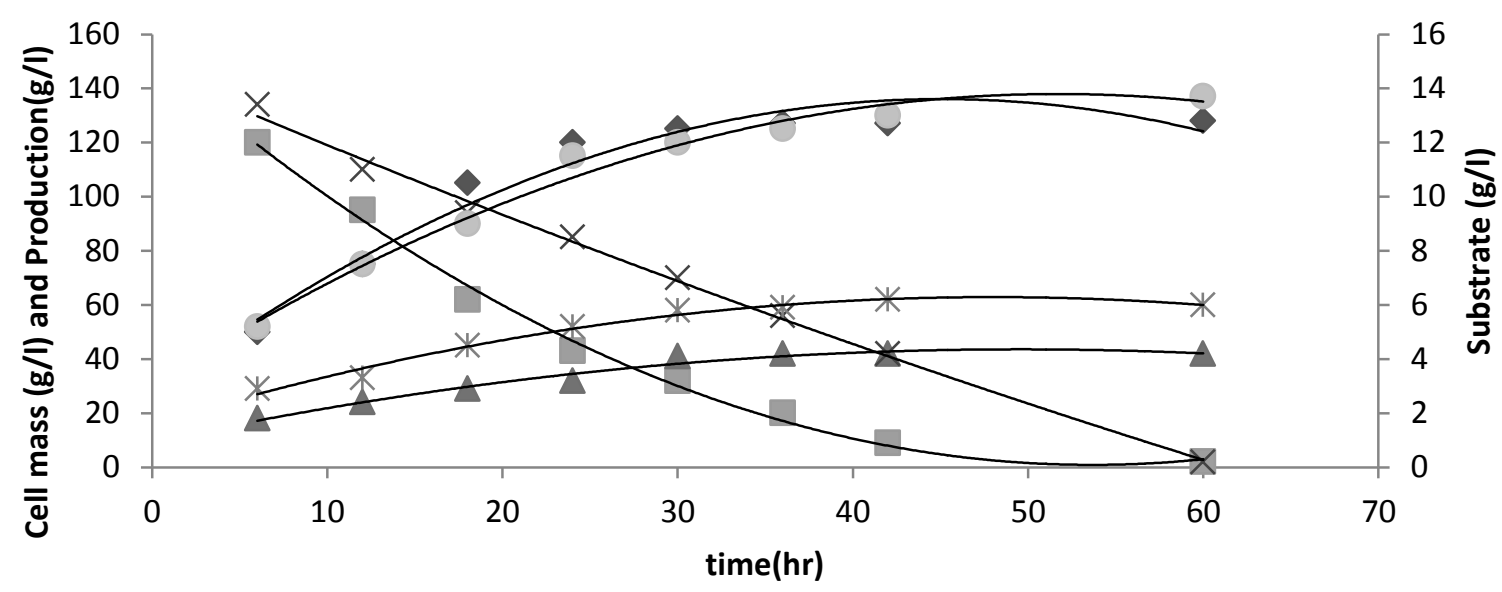

Substrate $(\mathrm{g} / \mathrm{l})$ at $5 \mathrm{pH} \quad \triangle$ Production $(\mathrm{g} / \mathrm{l})$ at $5 \mathrm{pH} \quad \times$ Substrate $(\mathrm{g} / \mathrm{I})$ at $5.5 \mathrm{pH} \quad--$ Model results * Production(g/l)at $5.5 \mathrm{pH} \diamond$ Cell Mass $(\mathrm{g} / \mathrm{l})$ at $5 \mathrm{pH} \quad$ Cell Mass $(\mathrm{g} / \mathrm{l})$ at $5.5 \mathrm{pH}$

Figure. 9: Ethanol production using molasses as carbon source at $\mathrm{pH} 5$ and 5.5

Numerical simulation was carried out to study the effects of different $\mathrm{pH}$ ranges on ethanol production. In figure $9.10 \%$ glucose $\& 15 \%$ glucose was used at $\mathrm{pH} 5$ and 5.5 , but the maximum ethanol production achieved at $10 \%$ glucose $\mathrm{pH} 5.5$ in figure 9 .

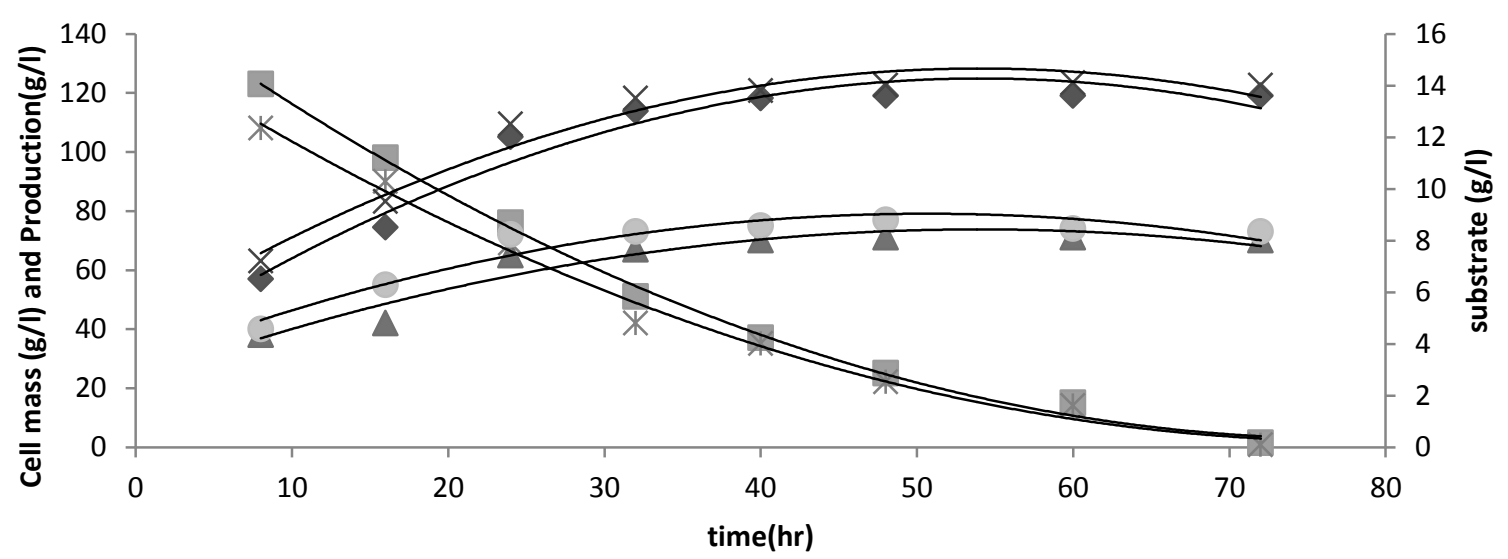

\begin{tabular}{|c|c|c|c|}
\hline Substrate $(\mathrm{g} / \mathrm{l})$ at $\mathrm{pH}=5$ & $\Delta$ Production(g/l)at $\mathrm{pH}=5$ & * Substrate $(\mathrm{g} / \mathrm{l})$ at $\mathrm{pH}=5.5$ & --Model results \\
\hline Production (g/l)at $\mathrm{pH}=5.5$ & Cell Mass $(\mathrm{g} / \mathrm{l})$ at $\mathrm{pH}=5$ & $\times$ Cell Mass $(\mathrm{g} / \mathrm{l})$ at $\mathrm{pH}=5.5$ & \\
\hline
\end{tabular}

Figure 10: Ethanol production using sucrose as carbon source at $\mathrm{pH} 5$ and 5.5 


\section{Effect of Agitation intensity on ethanol production using different carbon source}

Regarding ethanol production, in fermentation process agitator were used to provide homogeneous mixing between nutrient and microorganism for the growth. Regarding this agitation intensity had much significance to measure the value change in growth by changing rpm. Numerical simulation was carried out to measure the changes with respect to change in rpm, different rpm was used from 250-450 rpm and different carbon sources like sucrose, glucose and molasses for numerical simulation. The maximum ethanol production for sucrose as carbon source at $300 \mathrm{rpm}$ is about $15 \%$ sucrose shown in figure 12 . For glucose, the maximum ethanol production was observed at $15 \%$ glucose at $300 \mathrm{rpm}$ shown in figure 13 . In figure 14 molasses is used as a carbon source by utilizing about $10 \%$ and $15 \%$, but the maximum ethanol production was observed at $15 \%$ molasses at $300 \mathrm{rpm}$ using numerical simulation.

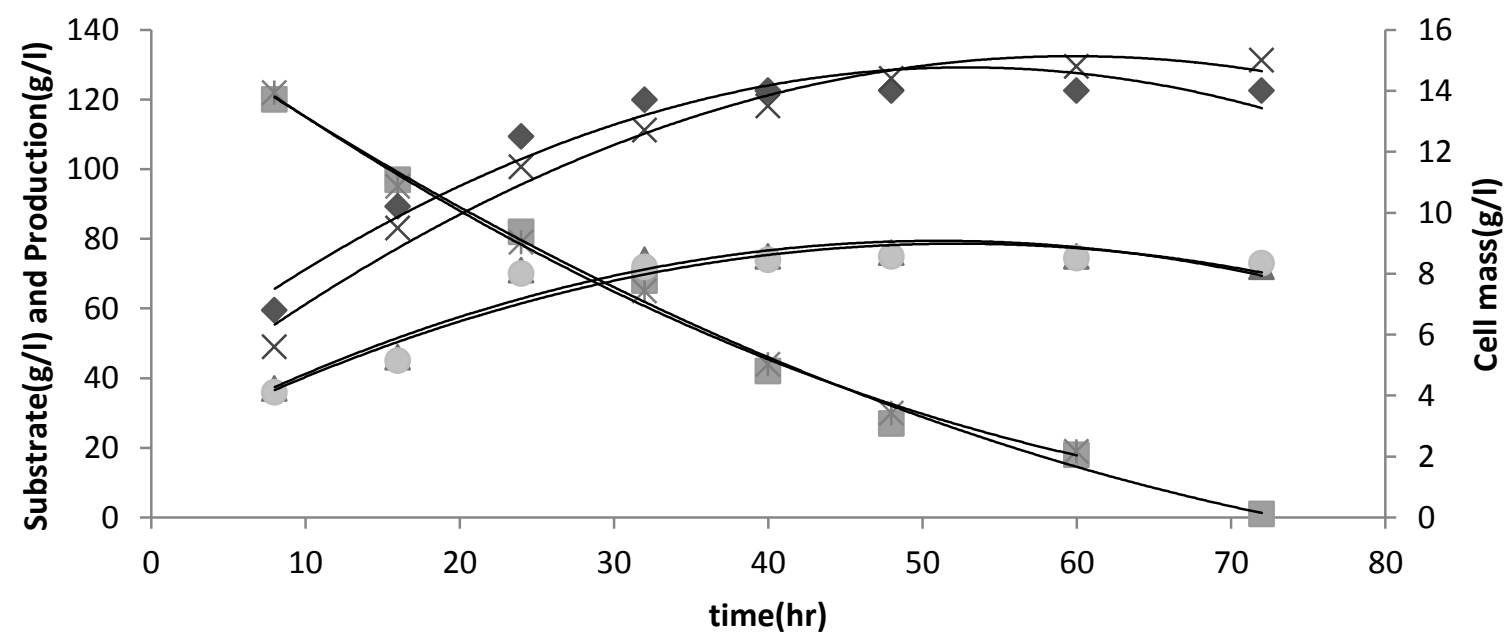

Substrate(g/l) at $300 \mathrm{rpm}$ * Substrate(g/l) at $250 \mathrm{rpm}$ - Cell Mass(g/l)at 300 rpm
$\triangle$ Substrate $(\mathrm{g} / \mathrm{l})$ at $300 \mathrm{rpm}$
--Model results
Production(g/l) at $250 \mathrm{rpm}$
$\times$ Cell Mass(g/l) at $250 \mathrm{rpm}$

Figure 11: Ethanol production using glucose as carbon source at 250rpm and 300rpm

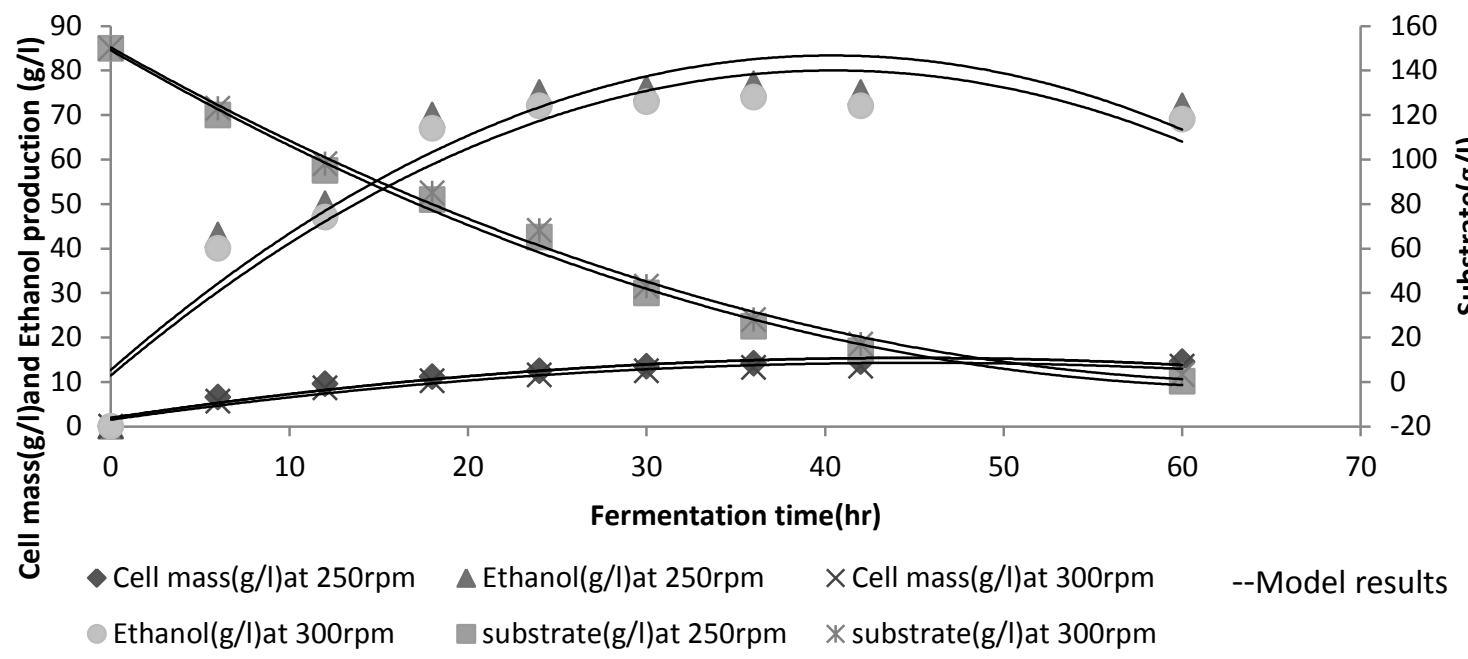

Figure 12: Ethanol production using molasses as carbon source at 250rpm and 300rpm 


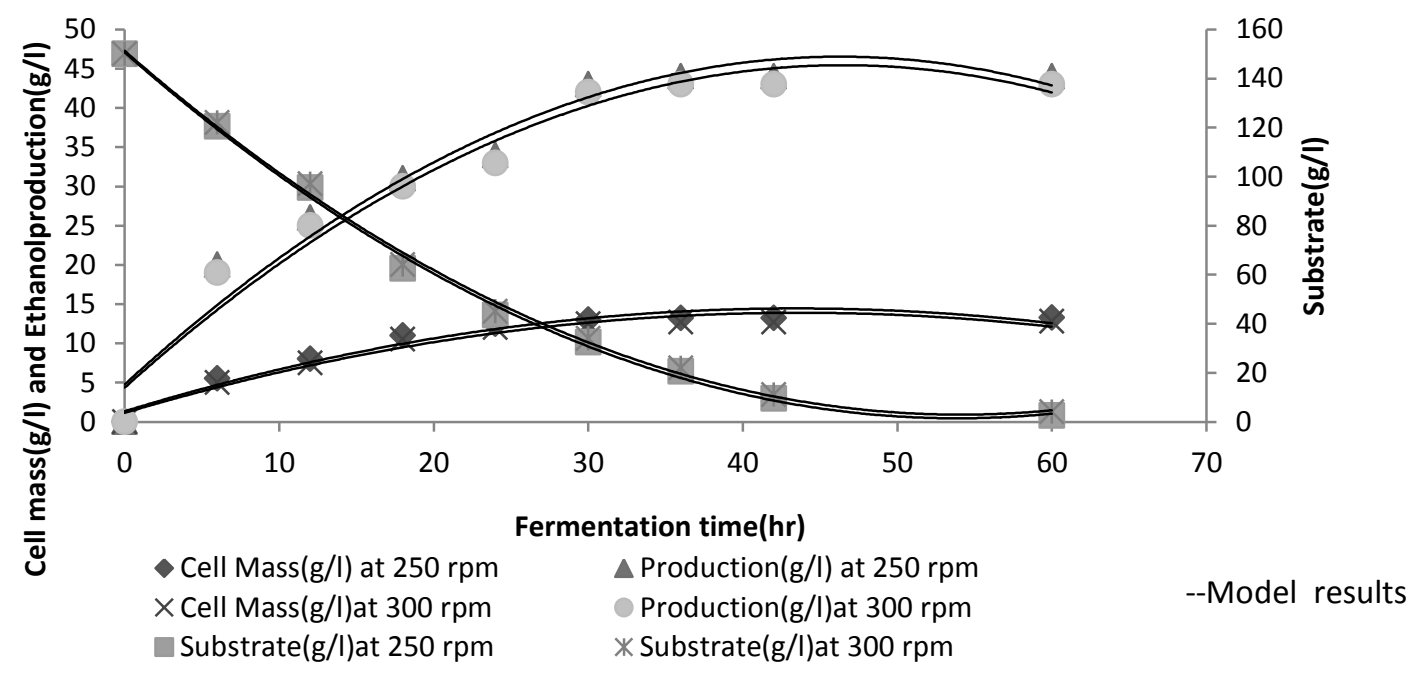

Figure 13: Ethanol production using molasses as carbon source at 250rpm and 300rpm

\section{CONCLUSION}

Numerical simulation could solve various differential equation in short period of time by utilizing appropriate numerical method. RK order 4 gave the best possible results regarding ethanol production from molasses by utilizing different carbon sources. During process of fermentation different carbon sources can be utilized, through this work. Experimental data and Monod model declared best possible results comparatively same. The maximum ethanol production $(76 \mathrm{~g} / \mathrm{l})$ was observed at $15 \%$ molasses, as for sucrose and glucose are concerned it gives lower value of ethanol production up to $73 \mathrm{~g} / \mathrm{l}$ by keeping other operational parameter under optimized condition such are $35^{\circ} \mathrm{C}, 300 \mathrm{rpm}, 0.2 \mathrm{vvm} / \mathrm{l}$ and $\mathrm{pH} 5.5$.

\section{REFERENCES}

- Baeyens J, Kang Q, Appels L, Dewil R, Lv Y, Tan T. (2015). Challenges and opportunities in improving the production of bio-ethanol. Progress in Energy and Combustion Science 47:60-88.

- Baptista CMSG, Coias JMA, Oliveira ACM, Oliveira NMC, Rocha JMS, Dempsey MJ, Lannigan KC, Benson PS. (2006). Natural immobilization of microorganisms for continuous ethanol production. Enzyme and Microbial Technology 40(1):127-131.

- Bouallagui H, Touhami Y, Hanafi N, Ghariani A, Hamdi M. (2013). Performances comparison between three technologies for continuous ethanol production from molasses. Biomass and Bioenergy 48:25-32.

- Cardona CA, Sánchez OJ. (2007). Fuel ethanol production: process design trends and integration opportunities. Bio-resource Technology 98(12):2415-2457.

- Cazetta, ML, Celligoi MAPC, Buzato JB, Scarmino IS. (2007). Fermentation of molasses by Zymomonas mobilis: Effects of temperature and sugar concentration on ethanol production. Bio-resource Technology 98(15):2824-2828.

- Mahar H, Jatoi AS, Gopang IA, Jalbani NB, Hussain S, Kumar D. (2017). Parametric Effect on Ethanol production through use of Monod Model. JFET 24(1):99-105. 
- Jatoi AS, Parkash, A, Aziz S, Soomro SA, Shah SF. (2016). Mathematical modeling of ethanol production from molasses using thermotolerant Kluyeromyces Marxians. Science International 28(1):319-322.

- Jatoi AS, Aziz S, Mahar H, Shah SF, Hussain S, Unar IN, Shahzad K. (2016). Numerical Simulation of ethanol production from molasses using thermos tolerant kluyeromyces Marxian's. JPIChE 44 (1):92 99.

- Najaf pour G, Younesi H, Ismail KSK. (2004). Ethanol fermentation in an immobilized cell reactor using Saccharomyces cerevisiae. Bio-resource Technology 92(3):251-260.

- Phisalaphong, M, Srirattana N, Tanthapanichakoon W. (2006). Mathematical modeling to investigate temperature effect on kinetic parameters of ethanol fermentation. Biochemical Engineering Journal 28(1):36-43.

- Rajoka MI, Latif F, Khan S, Shahid R. (2004). Kinetics of improved productivity of $\beta$-galactosidase by a cycloheximide-resistant mutant of Kluyveromyces marxianus. Biotechnology Letters 26(9):741-746.

- Shenoy D, Pai A, Vikas RK, Neeraja HS, Deeksha JS, Nayak C, Rao CV. (2011). A study on bioethanol production from cashew apple pulp and coffee pulp waste. Biomass and Bioenergy 35(10):4107-4111.

- Siqueira PF, Karp SG, Carvalho JC, Sturm W, Rodríguez-León JA, Tholozan, JL, Singhania RR, Pandey A, Soccol CR. (2008). Production of bio-ethanol from soybean molasses by Saccharomyces cerevisiae at laboratory, pilot and industrial scales. Bio-resource Technology 99(17):8156-8163.

- Walter A, Rosillo-Calle F, Dolzan, P, Piacente E, da Cunha KB. (2008). Perspectives on fuel ethanol consumption and trade. Biomass and Bioenergy 32(8):730-748.

- Wilkins MR, Widmer WW, Grohmann K. (2007). Simultaneous scarification and fermentation of citrus peel waste by Saccharomyces cerevisiae to produce ethanol. Process Biochemistry 42(12):1614-1619.

- Zayed G. (1997). Production of alcohol from sugar beet molasses without heat or filter sterilization. Journal of Industrial Microbiology and Biotechnology 19(1):39-42. 